\title{
Apigenin inhibits proliferation and migratory properties of Barrett's esophageal adenocarcinoma cells by targeting PI3K/Akt/mTOR pathway
}

\author{
Zhan Wang ${ }^{1}$ and Peng-yuan Zheng ${ }^{2 *}$ \\ ${ }^{1}$ Department of Gastroenterology, The Second Affiliated Hospital of Zhengzhou University, Zhengzhou, Henan 450014, \\ ${ }^{2}$ Department of Gastroenterology, The Fifth Affiliated Hospital of Zhengzhou University, No.3, Kangfu road, Zhengzhou, Henan \\ Province 450012, China
}

*For correspondence: Email: zhengpengyuan765@hotmail.com; Tel/Fax: 0086-0371-66916801

\begin{abstract}
Purpose: To investigate the effect of apigenin on Barrett's esophagus-associated esophageal adenocarcinoma (BEAC) cells OE33, and also to ascertain the mechanism by which it inhibits cellular proliferation and motility.

Methods: Proliferation index of OE33 in the absence and presence of apigenin was determined by methyl-thiazolyl-tetrazolium (MTT) assay and apoptosis was determined by enzyme-linked immunosorbent assay (ELISA) method. Boyden Chamber's assay was applied to determine the migration and invasion of control and apigenin-treated OE33 cells. Status of PI3K/Akt/mTor signaling was further determined by Western blotting in control and apigenin-treated cells.

Results: Apigenin resulted in the inhibition of the proliferation of OE33 cells in a dose- and timedependent fashion, with an $I_{50}$ of $75 \mu \mathrm{M}$, after $72 \mathrm{~h}$ of incubation, and also induced apoptosis, with modulation of pro- and anti-apoptotic genes. Furthermore, apigenin inhibited the motility of OE33 by targeting PI3K/Akt/mTOR signaling.

Conclusion: Apigenin effectively inhibits the oncogenicity of OE33 cells by targeting PI3K/Akt/mTOR pathway.
\end{abstract}

Keywords: Barrett's esophagus-associated esophageal adenocarcinoma (BEAC), Apoptosis, Migration, Anticancer

Tropical Journal of Pharmaceutical Research is indexed by Science Citation Index (SciSearch), Scopus, International Pharmaceutical Abstract, Chemical Abstracts, Embase, Index Copernicus, EBSCO, African Index Medicus, JournalSeek, Journal Citation Reports/Science Edition, Directory of Open Access Journals (DOAJ), African Journal Online, Bioline International, Open-J-Gate and Pharmacy Abstracts

\section{INTRODUCTION}

Apigenin [5,7-dihydroxy-2-(4-hydroxyphenyl)$4 \mathrm{H}-1$-benzo-pyran-4-one] is a dietary flavone, found abundantly in fruits and variety of vegetables including parsley, oranges, onions, tea, chamomile, wheat sprouts, etc $[1,2]$. Apigenin has immense therapeutic potential due to its anti-inflammatory, antiviral, antimutagenic as well as anticancer properties [2-10]. In certain cancer cells, apigenin has been known to target the PI3K/Akt/mTOR signaling leading to inhibition of oncogenicity [11-14].

Barrett's esophagus-associated esophageal adenocarcinoma (BEAC) has become the fastest growing tumor in the western world, within the last three decades $[15,16]$. In the United States alone, the incidence of BEAC had increased by $300 \%$ to $500 \%$ in the last 40 years [17] and recently published meta-analysis studies reveal that similar risk factors of Barrett's esophagus 
also prevail in Asian countries [18]. Barrett's esophagus (BE) is known to be the most significant precursor lesion for esophageal adenocarcinoma (EAC) [19], which resulted from the longstanding exposure of the esophageal mucosa to gastro-esophageal reflux, resulting in the metaplastic replacement of the native squamous epithelia by columnar cells (i.e. Barrett's mucosa) [20,21]. This epithelial population serves as the platform for the formation of intra-epithelial neoplasia, also termed as dysplasia, which thereafter might lead to the Barrett-related EAC $[20,21]$.

Since the effect of apigenin on BAEC is not investigated previously, we conducted this research to find out whether apigenin can inhibit BAEC. For our study we have used esophageal adenocarcinoma cell line OE33, as the in vitro model and also investigated the mechanism of apigenin action on OE33 cells.

\section{EXPERIMENTAL}

\section{Materials}

Apigenin was purchased from Sigma. Nutrient mixture Dulbecco's minimal essential medium (supplemented with $1 \mathrm{mM}$ L-glutamine), fetal bovine serum, penicillin-streptomycin, and 0.25 $\%$ Trypsin-EDTA were purchased from GIBCO (Invitrogen). Primary antibodies such as Bax, and $\mathrm{Bcl}-2$, were purchased from Santa Cruz Biotechnologies (Santa Cruz, CA, USA), whereas cleaved caspase-3, cleaved caspase9,PI3K (p85), p-Akt ( Ser473), and p-mTor (Ser2448) were purchased from Signaling Technologies (Beverly, MA, USA).

\section{Cell culture and maintenance}

BEAC cell line OE33, was purchased from American Type Culture Collection (ATCC). OE33 cells used in this study were from fifth through tenth passages and were routinely maintained in Dulbecco's Modified Eagle's Medium supplemented with $10 \%$ FBS and antibiotics , penicillin $(100 \mathrm{U} / \mathrm{mL})$, and streptomycin (100 $\mu \mathrm{g} / \mathrm{mL})$, at $37^{\circ} \mathrm{C}$ in a humidified chamber.

\section{Cell viability assay (MTT assay)}

Cultured OE33 cells were seeded in 96 well plate at a density of $1 \times 10^{4}$ cells $/ \mathrm{ml}$ and grown to confluency. Cell were then treated with different concentrations of apigenin (0-100 $\mu \mathrm{M})$ for 24,48 and $72 \mathrm{~h}$, respectively. After treatment, MTT solution was added to each well and the absorbance was measured on an ELISA reader
(MultiskanEX, Lab systems, Helsinki, Finland) at a wavelength of $570 \mathrm{~nm}$ according to published protocol (29). Data are presented as percent inhibition, calculated as in Eq 1.

Inhibition $(\%)=\{100-($ At-As $) / 100\}$

where At and As are the absorbance of the test substances and solvent control, respectively.

\section{Apoptosis assay}

Involvement of apoptosis in apigenin treated OE33 cells was determined using the apoptosis detection ELISA kit (Roche Diagnostic, USA) following. Briefly, control and apigenin-treated cells were subjected to lysis and centrifuged at $1500 \times \mathrm{g}$ for $15 \mathrm{~min}$. The cytosolic supernatant was collected, and the total protein was estimated. Around $10 \mu \mathrm{g}$ of protein, from each sample was added to streptavidin-coated well, containing $80 \mu \mathrm{L}$ of reaction mixture consisting of anti-histone-biotin and anti-DNA-peroxidase and incubated for $2 \mathrm{~h}$ with continuous shaking. Finally the chromagenic substrate ABTS (2,2ф-azino-di(3-ethylbenzthiazoline-6-sulfonic acid)) was added into each well to get a colored product, which was measured by the ELISA reader at $405 \mathrm{~nm}$.

\section{Determination of migration/invasion by Boyden Chamber assay}

Migratory properties of OE33 cells were determined by Boyden chamber assay, using track-etched polyethylene terephthalate membranes (Corning, MA), with $8.0 \mu \mathrm{m}$ diameter-pore size. OE33 cells were treated with apigenin $(0-75 \mu \mathrm{M})$ for $48 \mathrm{~h}$, and migration assay was performed accordingly. Invasion was performed following the published protocol, using Matrigel $₫$-coated invasion chambers (BD Biosciences). The cells which migrated/ invaded to the lower surface of the membrane were stained with crystal violet. The resultant crystal violet complex was then dissolved in $10 \%$ acetic acid and the absorbance was measured at 600 $\mathrm{nm}$, using the microplate reader (Multiskan EX, Lab systems, Helsinki, Finland) to determine the extent of migration or invasion.

\section{Western blot analysis}

Cultured OE33 cells after treatment with apigenin, were extracted in ice cold lysis buffer, constituted of $150 \mathrm{mM} \mathrm{NaCl}, 20 \mathrm{mM}$ Tris- $\mathrm{HCl}, 1$ $\% \quad N P-40,20 \mu \mathrm{g} / \mathrm{mL}$ leupeptin, $20 \mu \mathrm{g} / \mathrm{mL}$ aprotinin, $1 \mathrm{mM}$ ortho-vanadate, and $2 \mathrm{mM}$ PMSF, $\mathrm{pH}$ 7.4. Total protein from the cell lysates were estimated by Bradford method. 
Approximately, 30 - $50 \mu \mathrm{g}$ of protein from each sample was separated by 10 - $12 \%$ SDS-PAGE, electrophoretically transferred to polyvinylidene difluoride membrane, incubated with different monoclonal and polyclonal antibodies according to manufacturer's mentioned dilution and subsequently with required secondary antibodies. Then, the membranes were exposed to Kodak x-ray films after chemiluminescent treatment.

\section{Statistical analysis}

Analysis of data was achieved with GraphPad Prism version 4.00 (GraphPad Software, San Diego, California, USA). All data are expressed as mean \pm SD. Statistically significant differences between groups were determined by paired Student's two-tailed t-test. $P<0.05$ was considered statistically significant.

\section{RESULTS}

\section{Apigenin inhibits proliferation of OE33 cells}

Treatment of esophageal adenocarcinoma cells, OE33 with apigenin resulted in the decrease of cellular proliferation in both concentration and time-dependent fashion (Fig 1B). OE33 cells were treated with different concentrations of apigenin $(0-100 \mu \mathrm{M})$ for 24, 48 and $72 \mathrm{~h}$, respectively. A drastic reduction in the cell viability was observed after $72 \mathrm{~h}$ of treatment and the $I_{50}$ was observed at a concentration of 75 $\mu \mathrm{M}$ apigenin (Figure 1).

\section{Apoptosis and modulation of pro-and anti- apoptotic markers}

To find out the mode of cell death in apigenintreated OE33 cells we determined the involvement of apoptosis. In the presence of 50 $\mu \mathrm{M}$ apigenin, apoptosis was increased by 2.4fold, while in presence of $75 \mu \mathrm{M}$ apigenin, it was increased by 7.5 -fold. Thus the results indicate that apigenin can induce apoptosis in OE33 cells in a concentration -dependent fashion (Figure 2A). Moreover we also observed the status of Bax/Bcl-2 ratio in apigenin-treated OE33 cells. We observed that, the pro-apoptotic protein Bax is up regulated, while the anti-apoptotic protein $\mathrm{Bcl}-2$ is down regulated, the increasing concentrations of apigenin (Figure 2B and Figure 2C). Also significant up regulation of cleaved caspase-3 and caspase-9 were observed, suggesting that apigenin is activating the intrinsic apoptotic pathway in OE33 cells (Fig 2D and 2E).

A

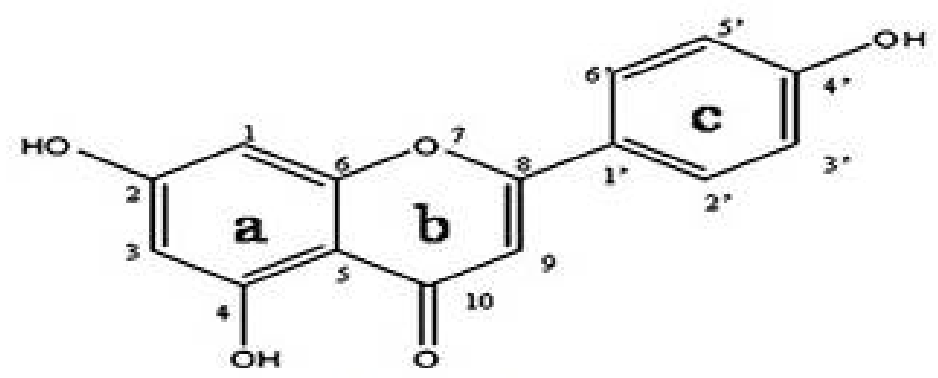

B

\section{Apigenin}

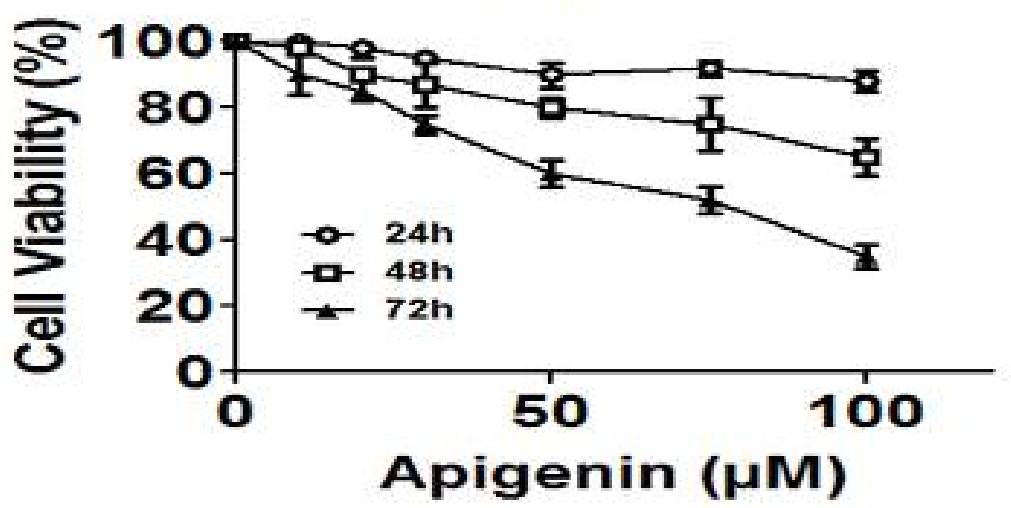

Figure 1: Inhibition of cell proliferation by apigenin. A. Chemical structure of apigenin. B. Approximately $60-70 \%$ confluent OE33 cells were grown in the presence or absence of different concentrations of apigenin $(0-100 \mu \mathrm{M})$ for $24 \mathrm{~h}, 48 \mathrm{~h}$ and $72 \mathrm{~h}$ respectively, and cellular viability/proliferation was determined using MTT assay. The results are expressed as mean \pm standard deviation of three independent experiments 
A

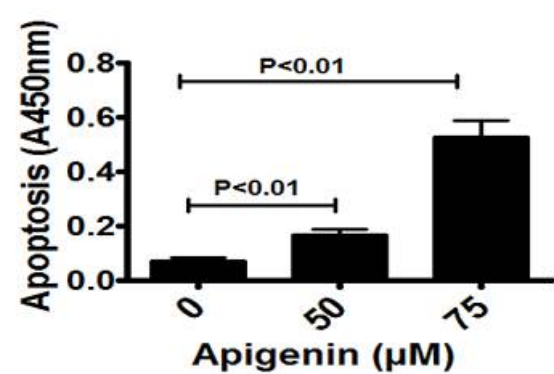

C

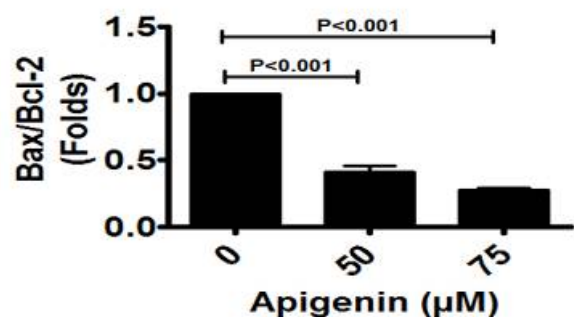

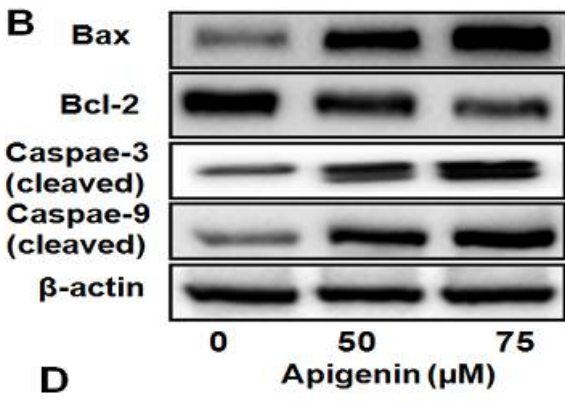

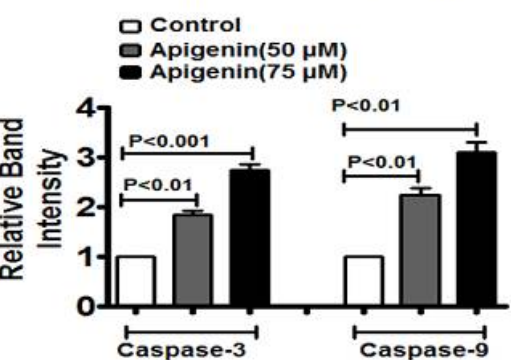

Figure 2: Induction of apoptosis and modulation of pro-and anti-apoptotic markers by apigenin. A. Apoptosis in OE33 cells, as determined using cell death detection ELISA kit. B. Expression of Bax, Bcl-2, cleaved caspase-3 and caspase-9 in control and apigenin treated OE33 cells. C. Bax/ Bcl-2 ratio. D. Relative band intensities for cleaved caspase- 3 and caspase- 9 . The results are expressed as mean \pm standard deviation of three independent experiments
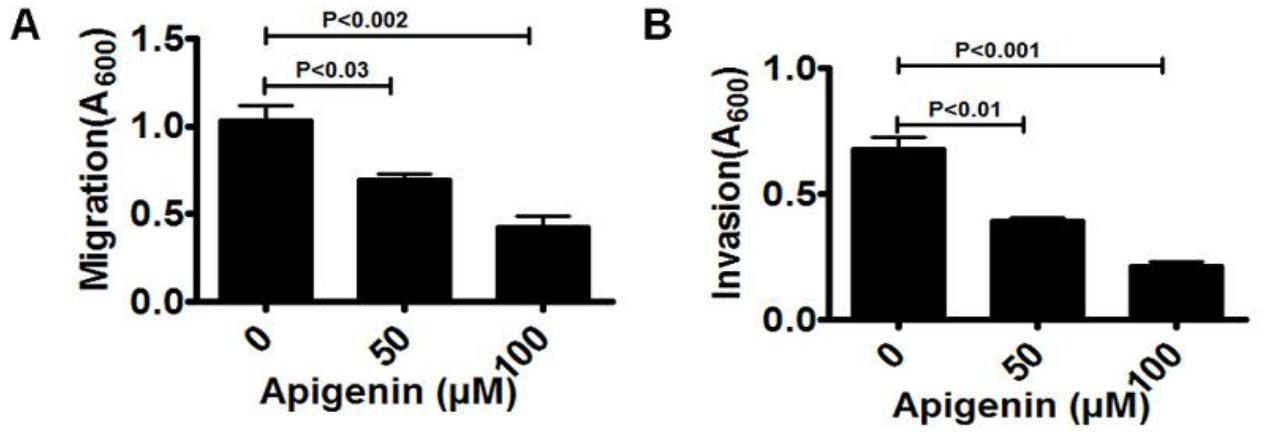

Figure 3: Inhibition of in vitro migration/invasion of OE33 cells by apigenin. OE33 cells were treated with different concentration of apigenin $(0-75 \mu \mathrm{M})$ for $72 \mathrm{~h}$ and extent of $\mathrm{A}$. migration and $\mathrm{B}$. invasion were determined by the Boyden Chamber assay. The results are expressed as mean \pm standard deviation of three independent experiments

A

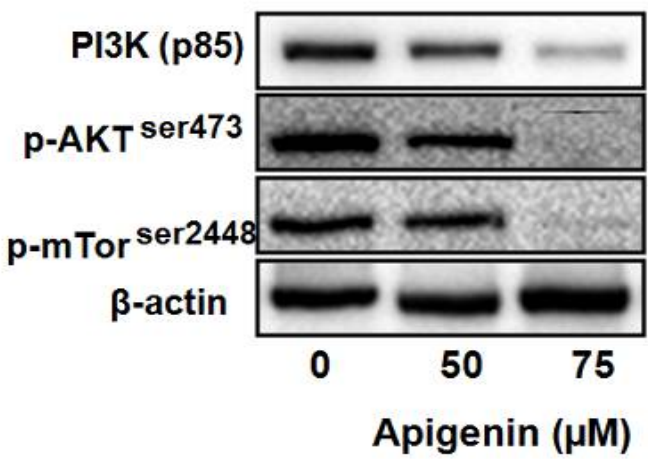

B

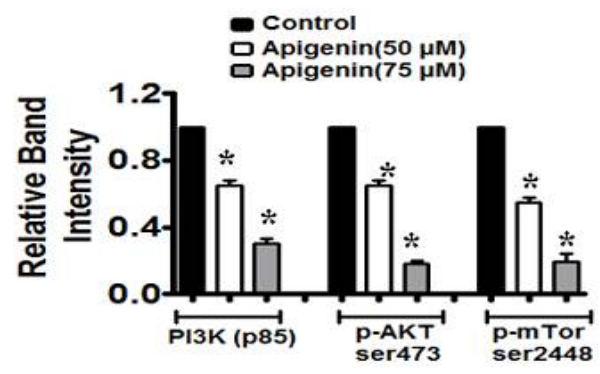

Figure 4: Effect of apigenin on PI3K/Akt/mTOR pathway. OE33 cells were treated with different doses of apigenin $(0-75 \mu \mathrm{M})$ for $72 \mathrm{~h}$, harvested and cell lysates were subjected to western blot. A. Western blot analysis

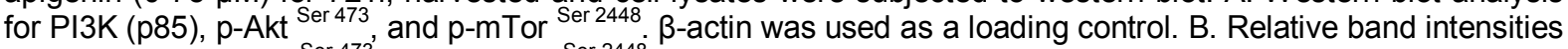
for PI3K (p85), p-Akt Ser 473, and p-mTor Ser 2448 . The results are expressed as mean \pm standard deviation of three independent experiments $\left[{ }^{*} p<0.05 \mathrm{vs}\right.$. apigenin-treated] 


\section{Apigenin inhibits the motility of OE33 cells}

Migratory or invasive properties of aggressive cancer cells are the hallmark of tumor metastasis. To find out whether, apigenin can inhibit the motility of OE33 cells we performed the migration as well invasion assays using the Boyden Chamber (Fig 3). Significant inhibition of cellular migration was observed at $50 \mu \mathrm{M}$ apigenin $(\sim 33 \%)$, while in presence of $75 \mu \mathrm{M}$ apigenin, the migration was reduced by almost $60 \%$ (Fig 3A). Similar pattern was observed when invasion assay was performed with apigenin-treated cells and the invasive phenotype of OE33 cells were inhibited by apigenin in a concentration dependent fashion (Fig 3B).

\section{Apigenin inhibits the PI3K/Akt/mTOR pathway in OE33 cells.}

$\mathrm{PI} 3 \mathrm{~K} / \mathrm{Akt} / \mathrm{mTOR}$ signaling plays vital role in cell proliferation, growth and survival and is one of the pathways frequently activated in cancer, including BEAC [17-19]. Many anticancer agents act by down regulating this signaling pathway, thus promoting apoptosis in cancer cells $(15,16)$. To further explore the mechanism of cell death caused by apigenin, the expression and phosphorylation status of the components of this signaling pathway were analyzed (Fig 4). We observed that, apigenin- treatment caused significant reduction in $\mathrm{p} 85$, the regulatory subunit of PI3K and also reduced the expression of phosphorylated (Ser 473) form of Akt. The effect of apigenin on mTOR activity was further investigated and exposure of OE33 cells to apigenin resulted in decrease in the level of activated form of mTOR (phosphorylated formSer2448), although the total Akt and mTOR levels remained unaffected by the treatment (data not shown).

\section{DISCUSSION}

The beneficial health effects of dietary phytochemicals have made them promising candidates for treatment and prevention of multiple diseases, including cancer. However, precise cellular and molecular targets for dietary supplements remain largely unknown. Apigenin is a dietary flavone, commonly associated with fruit- and vegetable-diets $[1,2]$. This dietary flavonoid has potential anticancer properties, but most importantly it has negligible adverse effects on noncancerous cell types. There was no earlier report of the mode of action of apigenin on esophageal adenocarcinoma or EAC. Hence in the present study we have investigated in detail, the mechanism by which apigenin imparts its growth inhibitory effect on EAC cells, OE33.

It was observed that apigenin exhibits superior anticancer properties by inhibiting the cellular proliferation of OE33 cells in both concentration and time-dependent fashion. Further experimental evidences confirmed that, this dietary flavonoid is effective in inducing apoptosis in OE33, in a concentration dependent fashion. Expectedly the $\mathrm{Bax} / \mathrm{Bcl}-2$ ratio was found to increase with increased apigenin concentration, confirming the involvement of apoptosis in apigenin mediated cytotoxicity. Furthermore, it was observed that apigenininduced apoptosis is mediated by caspase- 3 dependent pathway. Since BEAC is highly metastatic in nature, we determined whether apigenin can inhibit the motility of OE33 cells. Very interestingly, we observed that, apigenintreatment resulted in the inhibition of both migratory as well as invasive properties of OE33 cells in a concentration dependent fashion.

Considering the important role of $\mathrm{PI} 3 \mathrm{~K} / \mathrm{Akt} / \mathrm{mTor}$ signaling in the advancement of BEAC, we investigated whether apigenin can block this pathway in OE33 cells. Our western blot data confirmed that, apigenin targets this oncogenic signaling pathway in OE33cells. Expression levels of $p 85$, the regulatory subunit of PI3K, were drastically down regulated by apigenin in a concentration dependent fashion. Moreover the phosphorylation-dependent activation of the downstream modulators, such as p-Akt (Ser-473) and $\mathrm{p}$-mTor (Ser2448) were also inhibited by apigenin treatment.

\section{CONCLUSION}

The findings of the present study serve to delineate the anticancer mechanism of the dietary flavone, apigenin, against BEAC cells, which has the potential of a major therapeutic regimen against esophageal adenocarcinoma.

\section{DECLARATIONS}

\section{Acknowledgement}

The authors acknowledge Department of Gastroenterology, The Second Affiliated Hospital, and Department of Gastroenterology, The Fifth Affiliated Hospital of Zhengzhou University for research support.

\section{Conflict of Interest}

No conflict of interest associated with this work. 


\section{Contribution of Authors}

The authors declare that this work was done by the authors named in this article and all liabilities pertaining to claims relating to the content of this article will be borne by them.

\section{Open Access}

This is an Open Access article distributed under the terms of the Creative Commons Attribution License, which permits unrestricted use, distribution, and reproduction in any medium, provided the original work is properly credited.

\section{REFERENCES}

1. Patel D, Shukla S, Gupta S. Apigenin and cancer chemoprevention: progress, potential and promise (review). Int J Oncol 2007; 30: 233-245.

2. Yang CS. Inhibition of carcinogenesis and toxicity by dietary constituents. Advances in experimental medicine and biology. 2001; 500: 541-550.

3. Alhazmi MI. Molecular docking of selected phytocompounds with H1N1 Proteins. Bioinformation. 2015; 11: 196-202.

4. Choudhury D, Ganguli A, Dastidar DG, Acharya BR, Das A, Chakrabarti G. Apigenin shows synergistic anticancer activity with curcumin by binding at different sites of tubulin. Biochimie. 2013; 95: 1297-1309.

5. Gulluce M, Orhan F, Adiguzel A, Bal T, Guvenalp Z, Dermirezer LO. Determination of antimutagenic properties of apigenin-7-O-rutinoside, a flavonoid isolated from Mentha longifolia (L.) Huds. ssp. longifolia with yeast DEL assay. Toxicol Ind Health. 2013; 29: 534-40.

6. Gutierrez-Venegas G, Ventura-Arroyo JA, Arreguin-Cano $J A$, Ostoa-Perez MF. Flavonoids inhibit iNOS production via mitogen activated proteins in lipoteichoic acid stimulated cardiomyoblasts. Int immunopharmacol. 2014; 21: 320-327.

7. Lim R, Barker G, Wall CA, Lappas M. Dietary phytophenols curcumin, naringenin and apigenin reduce infection-induced inflammatory and contractile pathways in human placenta, foetal membranes and myometrium. Mol Hum Reprod. 2013; 19: 451-462.

8. Wu C, Chen F, Rushing JW, Wang X, Kim HJ, Huang G, et al. Antiproliferative activities of parthenolide and golden feverfew extract against three human cancer cell lines. J Med Food. 2006; 9: 55-61.
9. Lee WJ, Chen WK, Wang CJ, Lin WL, Tseng TH. Apigenin inhibits HGF-promoted invasive growth and metastasis involving blocking PI3K/Akt pathway and beta 4 integrin function in MDA-MB-231 breast cancer cells. Toxicol App Pharmacol. 2008; 226: 178-191.

10. Vargo MA, Voss $\mathrm{OH}$, Poustka F, Cardounel AJ, Grotewold E, Doseff Al. Apigenin-induced-apoptosis is mediated by the activation of PKC delta and caspases in leukemia cells. Biochem Pharmacol. 2006; 72: 681-692.

11. Gao AM, Ke ZP, Wang JN, Yang JY, Chen SY, Chen $H$. Apigenin sensitizes doxorubicin-resistant hepatocellular carcinoma BEL-7402/ADM cells to doxorubicin via inhibiting PI3K/Akt/Nrf2 pathway. Carcinogenesis. 2013; 34: 1806-1814.

12. Shukla S, Bhaskaran N, Babcook MA, Fu P, Maclennan GT, Gupta S. Apigenin inhibits prostate cancer progression in TRAMP mice via targeting PI3K/Akt/FoxO pathway. Carcinogenesis. 2014; 35: 452-460.

13. Tong $X$, Pelling JC. Targeting the PISKJAkt/mTOR axis by apigenin for cancer prevention. Anticancer Agents Med Chem 2013; 13: 971-978.

14. Yap TA, Garrett MD, Walton MI, Raynaud F, de Bono JS, Workman P. Targeting the PI3K-AKT-mTOR pathway: progress, pitfalls, and promises. Curr Opin Pharmacol. 2008; 8: 393-412.

15. Hamilton SR, Smith RR, Cameron JL. Prevalence and characteristics of Barrett esophagus in patients with adenocarcinoma of the esophagus or esophagogastric junction. Hum Pathol. 1988; 19: 942-948.

16. Wu TT, Watanabe T, Heitmiller R, Zahurak M, Forastiere $A A$, Hamilton SR. Genetic alterations in Barrett esophagus and adenocarcinomas of the esophagus and esophagogastric junction region. Am J Pathol. 1998; 153: 287-94.

17. Shaheen NJ. Advances in Barrett's esophagus and esophageal adenocarcinoma. Gastroenterology. 2005; 128: 1554-66.

18. Shiota S, Singh S, Anshasi A, El-Serag HB. Prevalence of Barrett's Esophagus in Asian Countries: A Systematic Review and Meta-analysis. Clinical gastroenterology and hepatology: the official clinical practice journal of the American Gastroenterological Association. 2015.

19. Spechler SJ, Souza RF. Barrett's esophagus. New Engl J Med. 2014; 371: 836-845.

20. Rugge M, Pizzi M, Castoro C. Definition of Barrett's esophagus dysplasia: are we speaking the same language? World J I Surg. 2015; 39: 559-565.

21. Rustgi AK, El-Serag HB. Esophageal carcinoma. New Engl J Med. 2014; 371: 2499-2509. 